\title{
Sunflower in Romanian agriculture
}

\author{
NICOLAE CSÉP \\ University of Oradea, Faculty of Environmental Protection, \\ Oradea, Romania \\ m_csep@yahoo.com
}

\section{Summary}

Romania is one of the largest producers of sunflower closely followed by Bulgaria, Hungary, France and Spain. The total sunflower production increased after 1990, due the increase of cultivated surface during the moderate yield average increasing rate. Last year, Romania was ranked first in the European Union (EU) for the area cultivated with sunflower and the total production of sunflower seeds, according to the National Statistics Institute (INS). Romania's position on the map of sunflower producers area is supported by about 1 million hectares sown. In the segment of sunflower productivity, Romania has an unfavourable position, situated in the last places in the classification of the EU's most productive agricultures. In order to increase production per hectare, it is required to perform measures aimed at the elements of sustainable cultivation technology, including the stability of the production level by ensuring phytosanitary protection.

Keywords: sunflower, cultivated surface, yield average, important diseases, integrated plant protection

\section{Introduction}

Sunflower is one of the most important crops in Romanian agriculture. The natural environment offers favorable conditions for growing sunflowers in the lowlands, hills and plateaus.

Areas of very favorable and favorable conditions can ensure the practice of advanced technologies through the use of hybrid performance and the application of high technology input, providing higher quantitative and qualitative levels. This ensures the economic efficiency as well as profitability of the crop (http://www.mediafax.ro/economic).

\section{Material and methods}

In the history of the crop some periods are distinguished by cultivation of various genotypes, from varieties with Russian origin (VNIIMK), followed by local varieties, adapted to the conditions and levels of existing technology (Record variety). 
An important step in the history of national and world technology was marked after 1970 by releasing the first sunflower hybrids (Romsun 52 and Romsun 53) by the researchers from Fundulea Research Institute for Cereals and Technical Plants, under the direction of Prof. Dr. Eng. A. V. Vrânceanu. The results of more than 50 years of activity could be summarized as follows: - breeding and releasing more than 340 cultivars and hybrids, adapted to the difficult environment of Romania (Hera, 1989; Păcureanu et al., 2007). Parallel to the development of the genetic background of cultivated forms, we have conducted researches on the integrated technology to ensure the stability of quality and quantity of production.

To increase performance of this plant requires the identification of weak links of culture management, identification of efficient methods and capabilities of the modern agricultural practice, followed by their application in accordance with natural conditions offered by specific ecological area.

The aim of this material is to present some available, domestic and international, statistical and professional information, applied technology features. By trying to signal some real possibilities provided by the research results obtained in recent years, available to individual growers and associates, may lead to an important increase of production quality and ensuring profitability of the culture.

\section{Results and discussion}

\section{Evolution of cultivated area}

Romania has a utilized agricultural area of 13.9 million hectares in the year 2013, compared with the French $(29 \mathrm{mln}$. ha), Spain (23.6 mln. ha), UK (17.3 mln. ha), Germany (16.7 mln. ha) and Poland (14.4 mln. ha) agriculture, but higher than that Italy $(13.1 \mathrm{mln}$. ha), Hungary (5.3 mil. ha) or Bulgaria (5.1 mil. ha) (http:/ / www.business-review.eu).

More than $60 \%$ of the agricultural area in Romania $(8.2 \mathrm{mil}$. ha) is arable land and about two-thirds of this area are used for cereal crops. Thus, Romania is one of the ten largest grain exporters in the world (No.9 in the world wheat export and No.6 in the case of corn) (http://www. mediafax.ro/economic/, http://www.business-review.eu).

Sunflower is a crop with major importance in Romanian agricultural crop production as the most important vegetable edible oil source (https:// www.cbi.eu/market-information/oilseeds/sunflower-seeds/europe/).

The cultivated area after 1990 increased rapidly, from 500000 ha to over 1000000 ha after 2012 (Figure 1). 
Figure 1. Evolution of surface cultivated with sunflower in Romania between 2007-2017

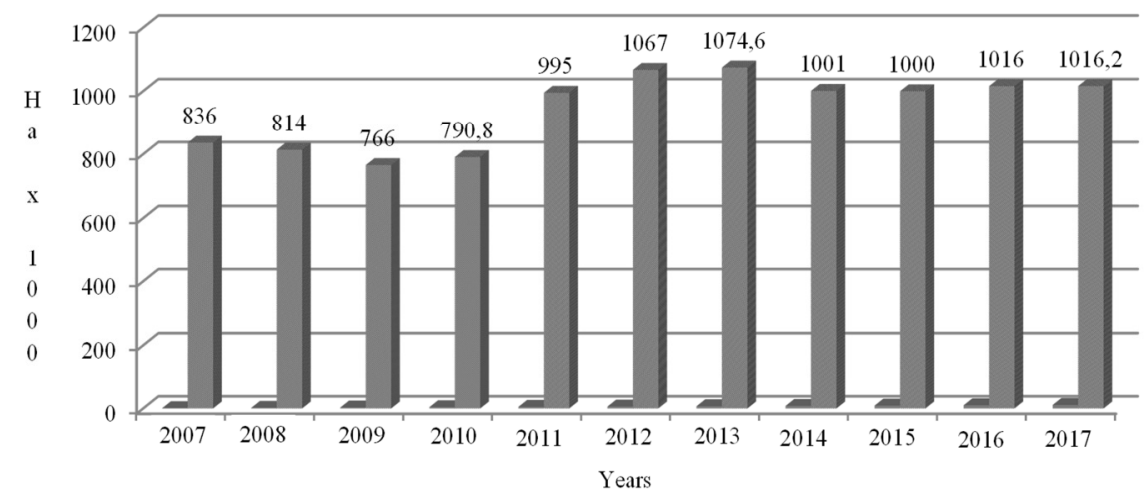

Source: FAOSTAT data, Romanian Statistical Yearbook, National Institute of Statistics Bucharest

The total sunflower production increased after 1990, due the modification of cultivated surface, during the moderate yield average increasing rate (Table 1). A growing in productivity per hectar to $2.5 \mathrm{t} \mathrm{ha}^{-1}$ may assure an increase in the total production of over 500000 tons, while mantaining as constant the cultivated sunflower surface.

Romania's position on the map of sunflower growers is supported by about 1 million hectares sown (https://www.worldatlas.com) (Mina, 2017). In the segment of sunflower productivity Romania has an unfavourable position, being situated on the last places in the classification of the EU's most productive agricultures.

Table 1. Evolution of cultivated surface, yield average and total sunflower production in Romania between 2007-2016

\begin{tabular}{llccrrr}
\hline \multicolumn{1}{c}{ Specification } & \multicolumn{1}{c}{ UM } & 2007 & 2008 & 2009 & 2010 & 2011 \\
\hline Surface & thousand ha & 835.9 & 813.3 & 766.1 & 790.8 & 995.0 \\
Average yield & $\mathrm{kg} \mathrm{ha}^{-1}$ & 654.0 & 1437.0 & 1433.0 & 1597.0 & 1798.0 \\
Total production & thousand $\mathrm{t}$ & 546.9 & 1169.7 & 1098.0 & 1262.9 & 1789.3 \\
\hline \multicolumn{1}{c}{ Specification } & UM & 2012 & 2013 & 2014 & 2015 & 2016 \\
\hline Surface & thousand ha & 1067.0 & 1074.6 & 1001.0 & 1000.0 & 1016.0 \\
Average yield & $\mathrm{kg} \mathrm{ha}^{-1}$ & 1310.0 & 1933.0 & 2187.0 & 1758.0 & 1923.0 \\
Total production & thousand t & 1398.2 & 2142.1 & 2189.3 & 1758.0 & 1954.0 \\
\hline
\end{tabular}

Source: FAOSTAT data, Romanian Statistical Yearbook, National Institute of Statistics Bucharest

The size class of agricultural holdings in Romania reveals a high proportion of farms with smaller acreage. The comparison regarding the increasing number of holdings with 50-100 and over 100 ha in two years appears in Table 2. The number of Romanian agricultural farms has a 
very high percent (32\%) out of the over 12 million farms registered in UE. In comparison, this indicator has a lower value in Hungary (5\%) (http:// ec.europa.eu/eurostat/web/ess/-/romanian-statistical-yearbook-2016).

An analysis of Romanian agriculture shows that in the last 20 years extreme fragmentation of land. a strategy for consolidating agricultural land is necessary to improve the agricultural performance, aimed at mitigating the degree of fragmentation of Romanian agriculture, at concentrating land in agricultural holdings (Aceleanu et al., 2015).

Table 2. Agricultural holdings in arable land, by size class of agricultural area in use in Romania $(2007,2010)$

\begin{tabular}{|c|c|c|c|c|c|c|c|}
\hline & \multicolumn{7}{|c|}{ Size class of agricultural area in use (hectares) } \\
\hline & Total & Under 0.1 & $0.1-0.3$ & $0.3-0.5$ & $0.5-1.0$ & $1.0-2.0$ & $2.0-5.0$ \\
\hline Years & \multicolumn{7}{|c|}{ Agricultural holdings (number) } \\
\hline 2007 & 286905 & 32 & 287 & 597 & 8317 & 47346 & 136514 \\
\hline \multirow[t]{3}{*}{2010} & 136172 & 169 & 1485 & 2044 & 8003 & 24765 & 58654 \\
\hline & \multicolumn{7}{|c|}{ Size class of agricultural area in use (hectares) } \\
\hline & $5.0-10.0$ & $10.0-20.0$ & $20.0-30.0$ & $30-50$ & $50-100$ & Over 100 & \\
\hline Years & \multicolumn{7}{|c|}{ Agricultural holdings (number) } \\
\hline 2007 & 63505 & 16094 & 2673 & 2335 & 1834 & 4371 & \\
\hline 2010 & 21468 & 6981 & 2149 & 2207 & 2539 & 5887 & \\
\hline
\end{tabular}

Source: www.insse.ro

The high number of farms with small area of culture limits the possibility of advanced cultivation technologies, reduce the positive effects of using the available performant agricultural equipments.

Aggregation of cultivated areas, the development of farms with surfaces of 50 and 100 hectares is one of the real possibilities of facilitating the application of advanced culture technology.

The average used area per farm has not changed significantly. Utilized agricultural area on average in 2016, per farm was of 3.65 ha compared to 3.60 ha in 2013 (www.insse.ro; http://www.nations encyclopedia.com/Europe/Romania-AGRICULTURE.html).

The average used area per unincorporated farm was 2.04 ha compared to 2.02 ha in 2013. The average used area per farm of legal personality was of 213.64 hectares, compared to 207.49 hectares in 2013.

This process is evolving, but the rhytm can be accelerated by individual growers associations or increasing investment of economically powerful actors interested in agricultural activity development (https:/ / www.gazetadeagricultura.info).

Providing legal conditions and facilities for that process of growth in the average of the farms size is a task and attribute of Romanian government and the legislative intitutions. 
An increased absorbtion rate of European funds guaranteed by EUfinanced projects is a possible way to concentrate the agricultural activity of young farmers, with receptivity to new technological elements.

\section{Environmental favorability}

Very favourable areal for growing sunflower includes: Romanian Great Plain, south Dobrogea, Olteniei Plain (cernozem soils, high level of nutrients, good water capacitaty) (Ion, 2010) . Recommended Romanian hybrids: Alex, Decor, Favorit, Festiv, Fundulea 206, Justin, Performer, Super and the foreigner intensive hybrids. The highest yields are obtained in this ecological area that includes 11 counties, with very favorable conditions for growing sunflower. Last year (2017) there were obtained production levels upper than $3500-4500 \mathrm{~kg} \mathrm{ha}^{-1}$ and more. There are concentrated important industrial processing capabilities, such as of the company Bunge (Buzau and Lehliu).

The second areal, favourable for sunflower cultivation includes: Western Plain (Timis, Arad, Bihor, Satu-Mare counties with chernozem soils, adequate rainfall quantity) - Romanian Great Plain, Dobrogei hills (brown soils, water deficit). Recommended Romanian hybrids: Alex, Felix, Festiv, Fundulea 206, Favorit, Performer, Romina, Rapid, Timis and the foreign hybrids. The production level in this areal in 2017 was often over 3000-3500 kg ha-1 in some individual farms from Sacuieni, Tulca, Ciumeghiu, Cenalos from Bihor County, Comlosu Mare from Timis County, Sanislau from Satu Mare County (https://agrointel.ro/author/ agrointeligenta).

The third areal, less favourable for this crop, includes Jijiei Plain, Barladului hills, Sub-Carpatian hills and Transilvaniei Plain (soils with lower fertility, errosion, temporary defficiency or exceeded water quantity) (Roman et al., 2012). Recommended Romanian hybrids: Alex, Festiv, Felix, Fundulea 206, Justin, Rapid, Super, Select and foreigner hybrids, especially with short vegetation period.

\section{Choosing the right variety / hybrid}

In Romania were registered a high number of hybrids, part of them are the result of Romanian sunflower breeders and most of them by foreign companies (Catalog ISTIS, 2007-2017).

A large number of hybrids were comercialised using modern technologies, based on the herbicid-resistance. The correct application of these technologies provides the ininterrupted develop in the early stages of plant vegetation. This ensures a continuous plant growth and development, which will result in higher production (www.agricultura romaneasca.ro/produse/hibrizi-de-floarea-soarelui). 
The hybrids created by Clearfield technology, using the trademark of BASF, are available on the market in Romania from 2013 (www.agriculturaromaneasca.ro/produse/hibrizi-de-floarea-soarelui-tehnologiaclearfield).

Pioneer began from 2016 marketing in Romania the first hybrid in its portfolio, with resistance to tribenuron metil. There are comercialised the new DuPontPioneer sunflower hybrids like P64LE25, with resistance to herbicide Express ${ }^{\circledR}$. This hybrid was the most cultivated hybrid in Romania last year (https://www.verdon.ro/seminte-plante-tehnice/ seminte-floarea-soarelui-p64le25-pioneer).

These hybrids were previously tested by tolerance against most aggressive races of Orobanche and downy mildew (Plasmopara halstedii) and have high ecological plasticity and stable production (https://www. cbi.eu/market-information/oilseeds/sunflower-seeds/europe).

\section{Integrated technological factors}

Tillage

Researches accomplished due to international collaborations (Dr. Sándor Balog ${ }^{\dagger}$ Ministry of Agriculture Budapest, Acad. József Vörös ${ }^{\dagger}$ Plant Protection Institut Budapest, Prof. Pál Békési, National Institute for Agricultural Quality Control and Gyakorlati Agrofórum; Dr. György Kis National Plant Protection Inspectorate and Agrofórum), have highlighted the role of stem shredding and incorporation of infected strain with Diaporthe helianthi, because the pathogen maintained their viability if the stems winters on ground surface. The incorporation is positively influenced and decreased viability of Sclerotinia sclerotium and Sclerotium bataticola sclerotia. Fragmentation and incorporating the infected stem after harvesting is an effective measure in reducing reserve of the pathogen's inoculum.

Using modern processing aggregates and soil preparation machinery ensures increased performance of work quality, which favors uniform emergence and development of plants in the early stages of vegetation.

\section{Sowing time}

Our former results showed that this technological factor can influence the natural resistence level of the hybrids in their relation with fungal pathogens.

In our experiments and comparative presentations of varieties and hybrids of sunflower, organized in different parts of the country and Western Plain, the different sowing time influenced between large limits intensity of infection of Diaporthe helianthi. Early sowing (before beginning of april) was generally more intensively infected in most years, 
because the sensitive stage in plant development (6-8 pear of leavesbudding stage) can coincide with the spreading time of ascospores (Table $3)$.

Table 3. Relationship between sowing time and Diaporthe helianthi infection in sunflower (ARDS Oradea, 1983-2005)

\begin{tabular}{llccc}
\hline \multirow{2}{*}{ Sowing period } & Genotype & \multicolumn{2}{c}{ Infection index $\%$} & \multirow{2}{c}{$\begin{array}{c}\text { Amplitude } \\
\text { of variation }\end{array}$} \\
\cline { 3 - 4 } & & Max. & Min. & +7.9 \\
\multirow{2}{*}{ Beginning of April } & Tolerant & 10.7 & 2.8 & +58.5 \\
\hline \multirow{2}{*}{ Middle of April } & Sensitive & 60.2 & 1.7 & +3.1 \\
& Tolerant & 4.1 & 1.0 & +23.5 \\
\hline \multirow{2}{*}{ Beginning of May } & Sensitive & 30.5 & 7.0 & +2.6 \\
& Tolerant & 3.0 & 0.4 & +9.6 \\
\hline
\end{tabular}

Density

Research conducted in the field of Agro-zootechnical Research Station Oradea during several series of experiments, some within FAO Network Sunflower topics, highlighted the need to respect the optimal density for each hybrid. Exceeding the optimum density can cause increased susceptibility of plants against infections caused by pathogens (Table 4).

Table 4. Influence of number of harvested plants on occurence of pathogens in sunflower (ARDS Oradea, 1983-2005)

\begin{tabular}{|c|c|c|c|c|c|c|c|}
\hline \multirow{3}{*}{$\begin{array}{c}\text { Plant } \\
\text { density }\end{array}$} & \multirow{3}{*}{ Genotype } & \multicolumn{6}{|c|}{ Infection index } \\
\hline & & \multicolumn{2}{|c|}{$\begin{array}{c}\text { Diaporthe } h . \\
\text { stems }\end{array}$} & \multicolumn{2}{|c|}{$\begin{array}{c}\text { Sclerotinia s. } \\
\text { stems }\end{array}$} & \multicolumn{2}{|c|}{$\begin{array}{c}\text { Alternaria } h . \\
\text { leaves }\end{array}$} \\
\hline & & Max. & Min. & Max. & Min. & Max. & Min. \\
\hline \multirow{2}{*}{45000} & Tolerant & 3.0 & 1.5 & 8.5 & 0.0 & 5.0 & 2.5 \\
\hline & Sensitive & 10.8 & 2.0 & 15.7 & 1.5 & 14.0 & 5.2 \\
\hline \multirow{2}{*}{60000} & Tolerant & 7.2 & 3.0 & 14.8 & 3.1 & 10.5 & 5.0 \\
\hline & Sensitive & 40.3 & 4.8 & 22.3 & 5.2 & 31.0 & 9.5 \\
\hline
\end{tabular}

The new intensive hybrids are adapted to technologies with high input technologies can support increasing density considered high for traditional domestic hybrids:

- 60 000-65 000 germinable seeds ha-1 to fertile soils and good moisture;

- 55 000-60 000 germinable seeds ha-1 to poor soils and low humidity.

The new hybrids with an increased ecological plasticity have extended the limit in sowing period, but due to the emergence of frequent weather anomalies in recent years caused by global climate change there is an increased risk of deviations from optimal density and periods for sowing time. 
Forerunner plants

Increased cultivated area raises the question of the possibility of application the rotation needed in terms of preventing the occurrence of soil borne pathogens attack.

Growing sunflowers on the same surface for several years is totally unrecommended.

Chosing as forerunner plant with receptivity to common fungal pathogens (oil raps, soya, mustard) must have negative influence on phytosanitary status of the sunflower (Muntean et al., 2008). To prevent the harmful inoculum accumulation in the soil, farmers are informed on the positive role of the use of most adequate forerunner plants, like cereals, early harvested corn, sugarbeet, peas. The adequate previous plant has an important role in the prevention of Sclerotinia sclerotiorum, Sclerotium bataticola, Plasmopara halstedii (Békési et al., 2014).

The expansion of raps (412 000 ha in 2016) (https://agrointel.ro/ author/agrointeligenta) and soybean area (178 000 ha in 2016) reduces the possibility of using this area for sunflower. Simultaneously, there was a decrease of the surfaces sown with wheat (decreasing with 2000000 ha in 2016) (www.economica.net). It may affect the possibility of making a rotation of five, or four years.

The most of recommended intensive hybrids have resistence to some races of Plasmopara halstedii. If these include indigenous fungal races too, they can provide limitation of primary infections of this fungus carried by seed and soil.

\section{Sunflower dieases}

During his history, sunflower was one of the healthiest cultivated plants. After the important changes in the 80 's, in the sunflower area appeared and expanded rapidly new fungal pathogens (Table 5), like Diaporthe helianthi with great influence on the quantity and quality (Horváth et al., 2006). The first signalisation of this fungus in Romania was reported /observed/ in the Western Plain of Romania in 1980 (Iliescu and Csep, 1982) and caused important production losses.

In the presence of the susceptible variety Record and very favourable climatic conditions of these years, the expansion of its areal raised rapidly. The pathogen was reported in the neighbour countries, too. Due to the common FAO research programme, researchers from Fundulea/ Romania, Szeged/Hungary, Novi Sad/Yugoslavia, General Toshevo/ Bulgaria have found sources of resistence in cultivated and wild genotypes (Stoenescu, 1987). The expansion and the level of production losses was stopped with the new technolocical elements like seed dressing and effective fungal treatmens during the vegetation period. 
Table 5. Important sunflower dieases in the Western Plain of Romania

\begin{tabular}{lcccc}
\hline \multirow{2}{*}{$<$ Disease } & Causal agent & \multicolumn{2}{c}{ Importance } & \multirow{2}{*}{ Trend } \\
\cline { 2 - 3 } & Plasmopara halstedii & $* * *$ & $* * *$ & $\geq$ \\
Downy mildew & Diaporthe helianthi & $* * *$ & $* *$ & $<$ \\
Stem kanker & Sclerotinia sclerotiorum & $* * *$ & $* * *$ & $=$ \\
White rot & Botrytis cinerea & $* *$ & $* *$ & $=$ \\
Grey mould & Sclerotium bataticola & $*$ & $* *$ & $>$ \\
Charcoal rot & Phoma macdonaldii & $*$ & $*$ & $=$ \\
Black spot & Alternaria helianthi & $* *$ & $*$ & \\
Brown spot & Alternaria spp. & & & \\
\hline
\end{tabular}

Source: ARS Oradea and Environmental Faculty Oradea

ARS Oradea, located in the area of maximum manifestation of Diaporthe helianthi infections and sclerotial fungi, contributed to genotype testing created in Fundulea (between 1972-2000) and by Pioneer (in 2000), testing the effectiveness of fungicides in seed treatment or used in the growing season (Vrânceanu et al., 1983, 2004; Vrânceanu, 2000). In ARS Oradea, in several research cycles, the main elements of the integrated control of pathogens (Table 6) and their influence on the level of infections in the most important fungal pathogens were tested and verified in research fields, trials, demonstration plots and farms.

\section{Conclusions}

Sunflower is one of the most important crops in Romania. Because cultivated area and total production in recent years, Romania has an important place among growing countries in Europe and worldwide. The high number of farms with small areas limited the possibility of large application of advanced cultivation technologies.

Research conducted in Romania during several series of experiments, some in international collaboration within the Sunflower FAO Network theme (Stoenescu, 1987), highlighted the need to respect the important elements of an integrated growing technology.

Crop rotation is a particularly important measure, because with this practice it's possible to regulate the population of soilborne pathogens (Sclerotium bataticola, Sclerotinia sclerotiorum, Plasmopara halstedii). An adequate crop rotation can reduce the quantity of inoculum in soil

In dry and warm summers and on sandy soils, sunflower was more intensively attacked by charcoal rot caused by Sclerotium bataticola like those from the northern part of Bihor county. The extension of the spreading area and the increasing infection index show that this fungus can develop in a really dangerous pathogen. 
Table 6. Influence of some integrated control measures on the presence of important sunflower pathogens

\begin{tabular}{|c|c|c|c|c|c|c|c|}
\hline Specification & 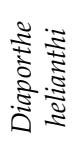 & 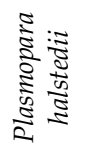 & 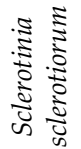 & 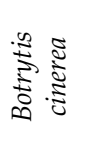 & 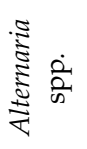 & 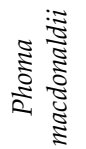 & 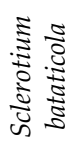 \\
\hline \multicolumn{8}{|l|}{ Agrotechnical measures } \\
\hline Tillage & +++ & + & + & + & & + & ++ \\
\hline Forerunner plant & + & +++ & +++ & + & & + & +++ \\
\hline Crop rotation & + & & & & & & \\
\hline Soving time & +++ & & +++ & +++ & & ++ & + \\
\hline Ferilization & +++ & & & & & & \\
\hline Plant density & +++ & + & +++ & ++ & +++ & ++ & + \\
\hline Prevention of volunteers & ++ & ++ & + & + & & + & + \\
\hline Weed control & + & + & ++ & ++ & ++ & + & + \\
\hline \multicolumn{8}{|l|}{ Biological measures } \\
\hline Tolerant/resistant hybrids & +++ & +++ & & & & ++ & +++ \\
\hline $\begin{array}{l}\text { Biofungicides, Coniothyrium } \\
\text { minitans, Tricoderma viride }\end{array}$ & & & + & + & & & + \\
\hline \multicolumn{8}{|l|}{ Chemical measures } \\
\hline Seed dressing & ++ & & & & & & \\
\hline Treatnments during vegetation & +++ & + & ++ & ++ & ++ & ++ & ++ \\
\hline Signalisation & +++ & + & ++ & + & + & + & + \\
\hline
\end{tabular}

Source: ARS Oradea and Environmental Faculty Oradea

Diaporthe helianthi can cause very important crop losses in the years with frequent rainfalls during June-July, because the sensitive stage in plant development (6-8 pairs of leaves- budding stage) coincided with the spreading time of ascospores. The fungus remains an important sunflower pathogen, with great infection potential, not only for this country.

Like in some neighbouring countries and in Europe in general, in the last years local downy mildew race populations have been diversified with new races, partially occured indigenously or being imported from outside (Virányi, 2008). The combination of using hibryds with resistence genes, seed dressing using systemic fungicides with various active ingredients will ensure the protection of the crop against primary infections caused by infected seed, overwintered oospores and the secondary, but becomed systemic infections caused by this harmful pathogen.

An environment-adapted complex of technological practices (growing resistant hybrids, crop rotation, optimal sowing time, plant density, chemical fertilization, fungal treatments in the vegetation period, weed control) can ensure a satisfactory level of sunflower protection against dominant parasites. Application of fungicides to control major parasites 
by efficient fungicide combinations in seed disinfection and in prevention during the growing season, based on forecasting method, adapted to individual conditions can contribute in increasing the efficiency of treatments, yield quality and its stability.

\section{References}

Aceleanu, M. I--Molanescu, A. G.-Craciun, L.-Voicu, C. (2015): The status of Romanian agriculture and some measures to take. Theoretical and Applied Economics. Volume XXII. 2. 603: 123-138.

Békési P.-Csöndes Izabella-Kadlicskó S. (2014): Veszélyes növénybetegségek (II. 9.). A napraforgó hamuszürke szárkorhadása. Agrofórum. 2014 június.

Hera, C.-Sin, Gh.-Toncea, I. (1989): Cultura florii-soarelui. Ceres Publishing House. Bucharest.

Horváth Z.-Békési P.-Virányi F. (2006): A napraforgó növényvédelmi technológiája. http://www.agraroldal.hu/napraforgo-technologia.html. Növényvédelem (7)

Iliescu, H.-Csep, N. (1982): Notă privind starea fitosanitară a culturilor de floarea soarelui în Câmpia de Vest în anul 1981. Probl. de prot. plantelor. 10. 1: 90-91.

Ion, V. (2010): Fitotehnie. Curs Uniuversitar, Fac. Horticultură Bucharest. www.horticultura-bucuresti.ro/images/pdf/Fitotehnie.pdf

Mina, I. (2017): Producția de floarea-soarelui a României a înregistrat un record istoric: 3,167 milioane de tone. BURSA 20. 10. 2017.

Muntean, L. S.-Borcean, I.-Axinte, M.-Roman, G. V. (2008): Fitotehnie. Academic Pres Publishing House. Cluj Napoca.

Păcureanu-Joița, M.-Vrânceanu, A. V.-Stanciu, D. (2007): Cincizeci de ani de activitate în ameliorarea florii-soarelui la Fundulea. Anals ICCPT. Fundulea. Vol. LXXV.

Roman, G.V.-Tabara, V.-Pirsan, P.-Robu, T. (2012): Fitotehnie.Vol. II. Universitară Publishing House.

Stoenescu, F. M. (1987): Information and Reports. The Sixth Consultation of the FAO Research Network on Sunflower. Szeged. Hungary. July 28-31 1987. http://isasunflower.org/fileadmin/documents/HELIA_issues/Helia10/H LIA_10_-_PAGE_63.pdf

Virányi, F. (2008): Research progress in sunflower diseases and their management. Proc. 17th International Sunflower Conference. Córdoba. Spain. 1-12.

Vrânceanu, A. V.-Csep, N.-Pîrou, N.-Stoenescu, F. M. (1983): Genetic variability of sunflower reaction to the attack of Phomopsis helianthi. Helia. 6: 23-25.

Vrânceanu, A. V. (2000): Floarea-soarelui hibridă. Ceres Publishing House. Bucharest.

Vrânceanu, A. V.-Iliescu, H.-Ioniță, A.-Popescu, A. (2004): Tehnologii agricole Cultura floriisoarelui. GEEA. Bucharest. 